Asian J. Med. Biol. Res. 2018, 4 (1), 44-48; doi: 10.3329/ajmbr.v4i1.36820

\author{
Asian Journal of \\ Medical and Biological Research \\ ISSN 2411-4472 (Print) 2412-5571 (Online) \\ www.ebupress.com/journal/ajmbr
}

\title{
Article \\ Effect of scion defoliation and stock leaf retention on growth of grafted lime (cv. Bau lime-1)
}

\author{
Ashrafun Nahar*, Md. Shahidul Haque Choudhury and Md. Abdur Rahim \\ Department of Horticulture, Bangladesh Agricultural University, Mymensingh-2202, Bangladesh
}

*Corresponding author: Ashrafun Nahar, Department of Horticulture, Faculty of Agriculture, Bangladesh Agricultural University, Mymensingh-2202, Bangladesh. Phone: +8801745762255; E-mail: ashrafunbau2012@gmail.com

Received: 18 February 2018/Accepted: 26 February 2018/ Published: 29 March 2018

\begin{abstract}
The present experiment was conducted at the Germplasm Centre (GPC) of the Fruit Tree Improvement Program (FTIP), Bangladesh Agricultural University, Mymensingh, during the period from June to October, 2013 to investigate the effects of scion defoliation and stock leaf retention on growth of grafted Lime (cv. BAU lime-1). The experiment consisted of two factors such as Factor A: four scion defoliation periods viz., defoliation before 9 days of grafting, defoliation before 6 days of grafting, defoliation before 3 days of grafting and defoliation on the day of grafting and Factor B: retention of leaf on rootstock below graft union viz., rootstock with leaf and rootstock without leaf. The study was laid out following Randomized Complete Block Design (RCBD) with three replications. The grafts were kept under observation in poly tunnel condition. Results revealed that highest graft height, $(45.47 \mathrm{~cm})$, number of leaves (15.72) and branches (2.92), length of the largest leaf $(8.45 \mathrm{~cm})$, breadth of the largest leaf $(3.77 \mathrm{~cm})$ were observed when scions were defoliated 6 days before grafting and lowest graft height $(38.72 \mathrm{~cm})$, number of leaves (12.12) and branches (2.25), length of the largest leaf $(5.60 \mathrm{~cm})$, breadth of the largest leaf $(3.37 \mathrm{~cm})$ were observed when scions were defoliated on the day of grafting. In respect of retention of leaves on rootstock, the highest graft height $(43.83 \mathrm{~cm})$, number of leaves (15.62) and branches (2.82), length of the largest leaf $(7.47 \mathrm{~cm})$, breadth of the largest leaf $(3.78 \mathrm{~cm})$ were found when grafting was done on rootstock with leaves and lowest graft height $(39.78 \mathrm{~cm})$, number of leaves (11.32) and branches (2.48), length of the largest leaf $(6.57 \mathrm{~cm})$, breadth of the largest leaf $(3.40 \mathrm{~cm})$ were found when grafting was done on rootstock without leaves. Therefore, the maximum growth in grafted lime seedlings can be achieved if scion defoliated 6 days prior to grafting operation and leaves are kept on root stock below graft union.
\end{abstract}

Keywords: scion defoliation; stock leaf retention; growth; lime

\section{Introduction}

Climatic condition of Bangladesh is suitable for growing many tropical and sub-tropical fruits. Only some major fruits like mango, pineapple, banana, litchi, lemon, guava, papaya, coconut are grown in large scale in the country. Lime (Citrus aurantifolia) is remarkable among the fruits, which is one of the important, popular and nutritious fruits in the world. Only 68721 metric tons lime and lemon were produced in 5786 acres land during the year 2014-2015 (BBS 2015). Lime under the family Rutaceae probably originated in India and then spread to the Middle East and other tropical and subtropical countries. The current major citrus producing countries in the world are Spain, USA, Israel, Morocco, South Africa, Japan, India, Turkey and Cuba (Patil, 2009). The health benefits of citrus fruit have mainly been attributed to the presence of bioactive compounds, such as phenolics (e.g. flavanone glycosides, hydroxycinnamic acids) vitamin $\mathrm{C}$ and carotenoids. There are about 37 limonoid aglycones and 19 glucosides in C. aurantifolia and their hybrids (Patil, 2009). Due to the high content of vitamin $\mathrm{C}$, citrus fruits are used in the treatment of scurvy. The anti-scurvy effect of citrus fruits is very 
strong because of the balanced composition of organic acids and minerals. Citrus aurantifolia fruits can be processed to obtain food products such as dehydrated citrus products or marmalades, jams, sorbet, pickles, candies and sugar boiled (Okwe, 2008). The peel contains volatile oil which is used in the production of drugs, perfumes, soaps, hair cream, body oil and other cosmrtics as well as other home cleaning products (Ferguson, 1990). Lime is mainly propagated by seed and air layering in the country. In case of seed propagation; there are some disadvantages. In some cases, seedlings are not true-to-type with mother tree; due to juvenility factors, seedling trees do not usually bear fruit until they are nearly a decade old; and they are vulnerable to unfavorable soil conditions, diseases, and so forth. But the vegetative method is desirable because it enables to retain the characteristics of the mother plant, to get flower and fruit earlier, to remain initially relatively smaller with the benefit of more plants accommodation per unit area and to give the growers earlier fruit and more economic benefit. Growth of grafted plant depend on several factors including time of operation, grafting method, defoliation period of scion, age of the rootstock and leaf and node retention of rootstock. Plant height, number of leaves and branch, length and breadth of largest leaf are important parameter of plant growth, the present study was undertaken to investigate the effects of scion leaf defoliation and stock leaf retention of cleft grafting on growth of the grafted lime plants.

\section{Materials and Methods}

\subsection{Location}

The present experiment was conducted at the 'BAU Germplasm Centre (GPC) of Fruit Tree Improvement Program (FTIP), Bangladesh Agricultural University, Mymensingh during the period from June to October, 2013.

\subsection{Experimental materials}

High yielding cultivar namely FTIP BAU Kagozi Lebu-1 (Semi-seedless) was used in this study. The rootstocks used in the experiment were raised in polybag from the lemon seeds of unknown variety. The scion shoots used, were collected from mother plants of lime (cv. BAU Lebu-1).

\subsection{Design and layout of the experiment}

The two-factor experiment consisting of 8 treatment combinations was laid out in Randomized Complete Block Design (RCBD) with three replications. For each treatment combination grafting operations were performed on twenty rootstocks of each plot of a block. Thus in total $4 \times 2 \times 3 \times 20=240$ grafts were made.

\subsection{Treatments of the experiment}

The experiment consisted of two factors, Factor A: scion defoliation period viz., Defoliation before 9 days of grafting, Defoliation before 6 days of grafting, Defoliation before 3 days of grafting, Defoliation on the day of grafting and Factor B: Stock leaf retention viz., Rootstock with leaves below graft union Rootstock without leaves below graft union.

\subsection{Tools used}

Secateurs, Sharp grafting knife, Measuring scale, Measuring tape, Polythene cap, Polythene strip, Polybag, Thick needle, Thread etc.

\subsection{Grafting operation}

Grafting operation was performed on 25th June, 2013. Scions of $10 \mathrm{~cm}$ long scions containing about three nodes were used for grafting operation. In this method of grafting about 2-3 cm long two smooth slanting cuts were made at the proximal end of the scion on both sides opposite to each other in such a way that the end portion became very thin. It was done with the help of sharp knife. The smooth long slanting cuts at the base of the scion gave an appearance of a sharp chisel. The rootstock was at first deheaded by giving slanting cut and then a vertical split cut was made by a thin and sharp bladed grafting knife at the centre of the slanting cut surface of the stock having a depth of approximately $2-3 \mathrm{~cm}$. Then, the scion was inserted into the wedge cut of rootstock through slight opening the splits. Thus both components were brought into close contact particularly cambia in face to face and tied firmly with polythene strip. After wrapping the graft union, the scion along with the union portion was covered with a polythene cap to protect the scion from loss of moisture through transpiration. In this method, both the stock and scion were of same thickness to match each other. The grafts just after their preparation were shifted to the poly tunnel and placed as per layout of the experiment. After 60 days the grafts were shifted to the normal open condition. 


\subsection{Data collection}

The data were collected on the following parameters:

1. Graft Height

2. Number of leaves per graft

3. Number of branches per graft

4. Length of the largest leaf

5. Breadth of the largest leaf

\subsection{Statistical analysis}

The collected data on graft height, number of leaves, number of branches, length of the largest leaf and breadth of the largest leaf were collected and statistically analyzed to find out the significance of differences between the treatments and treatment combinations. The means of all the treatments were calculated and the analyses of variances (ANOVA) for all the characters were performed by ' $\mathrm{F}$ ' variance test. The significance of differences between treatments means were compared by Least Significant Difference (LSD) test (Gomez and Gomez, 1984).

\section{Results and Discussion}

\subsection{Effect of scion defoliation period}

Significant variations were observed in all parameters due to the effect of scion leaf defoliation period. Among the four scion leaf defoliation periods the highest graft height $(45.47 \mathrm{~cm})$, number of leaves $(15.72)$ and branches (2.92), length of largest leaf $(8.45 \mathrm{~cm})$, breadth of largest leaf $(3.77 \mathrm{~cm})$ were observed when scion shoots were defoliated 6 days before grafting (Table 1). These variations in different parameters might be due to the better efficiency of defoliated scion shoots over undefoliated ones. Better efficiency of defoliated scion might be due to the fact that defoliation causes an immediate rise in sucrose content of phloem sap of the shoots. This helps in movement of solutes towards the apex of the shoots and thereby resulting in initiation of higher meristamatic activity at the bud level. This condition helps in better sap flow and good callus formation due to stimulation of cambium division favoring better graft union (Maiti and Biswas, 1980).

The graft height was significantly influenced by different scion defoliation periods, the highest graft height $(45.47 \mathrm{~cm})$ was found when the grafting was done with the scion defoliated 6 days before grafting and the lowest graft height $(38.72 \mathrm{~cm})$ was recorded from scion defoliated on the day of grafting. Higher vigor could be attributed to growth activity of buds of scion which get activated after defoliation which enhanced the length of rootstock and scion. These results are in line with Dhakal and Honda (1986).

Table 1. Effect of scion defoliation period on graft height, number of leaves per graft, number of branch per graft, length of largest leaf and breadth of largest leaf at 90 days after grafting.

\begin{tabular}{lllcccc}
\hline $\begin{array}{l}\text { Scion defoliation period } \\
\text { before grafting(days) }\end{array}$ & $\begin{array}{l}\text { Graft height } \\
\text { (cm) }\end{array}$ & $\begin{array}{l}\text { Number } \\
\text { leaves }\end{array}$ & $\begin{array}{c}\text { of } \\
\text { bramches }\end{array}$ & $\begin{array}{l}\text { Length } \\
\text { largest leaf(cm) }\end{array}$ & $\begin{array}{l}\text { Breadth of largest } \\
\text { leaf(cm) }\end{array}$ \\
\hline 9 & 42.33 & 12.67 & 2.75 & 6.35 & 3.50 \\
6 & 45.47 & 15.72 & 2.92 & 8.45 & 3.77 \\
3 & 40.70 & 13.05 & 2.67 & 6.57 & 3.73 \\
0 & 38.72 & 12.12 & 2.25 & 5.60 & 3.37 \\
LSD at 5\% & 0.04 & 0.92 & 1.01 & 0.20 & 0.22 \\
LSD at 1\% & 0.05 & 1.28 & 1.39 & 0.28 & 0.31 \\
Level of significance & $* *$ & $* *$ & $* *$ & $* *$ & $* *$ \\
\hline
\end{tabular}

The maximum number of leaves (15.72) and branches (2.92) per graft were recorded in case of grafts obtained from scions defoliated 6 days before grafting this might be due to early bud breaking; resulting in early and better union of stock and scion thereby making the nutritional supply in required quantity easily giving quick growth of graft. On the other hand the lowest number of leaves (12.12) and branch (2.25) per graft was recorded when grafting was done with the scion defoliated on the day of grafting. This result is in agreement with the findings of Aftab (2004). Different scion leaf defoliation period of lime also significantly influenced the length and breadth of the largest leaf of the grafts. The lowest leaf length in case of scions defoliated on the day of grafting may be due to late bud breaking and secondary sprouting. The influence of curing on growth parameters could be attributed to initiation of cambium activity which might have resulted from defoliation (Hartman et al., 1997). Importance and beneficial effects of scion treatment through defoliation on the growth of mango grafts have also been emphasized by Patil et al. (1981), Reddy and Melanta (1988). 


\subsection{Effect of stock leaf retention}

Rootstocks directly affect the ability of plants to take up water and nutrients and significantly alter the pattern of canopy development and photosynthesis. The highest graft height $(43.83 \mathrm{~cm})$ found in grafts with leaf below grafting union (Table 2) this might be also due to the increased photosynthetic rate, mobilization of food reserves and juvenility of rootstock and the normal activity of cells which is enhanced by proper photosynthesis that promotes earlier sprouting and their continual growth. This result is also proved by Khatun (2005).

Table 2. Effect of stock leaf retention on graft height, number of leaves per graft, number of branch per graft, length of largest leaf and breadth of largest leaf at 90 days after grafting.

\begin{tabular}{lccccc}
\hline Stock leaf retention & $\begin{array}{l}\text { Graft } \\
\text { height }\end{array}$ & $\begin{array}{l}\text { Number } \\
\text { leaves }\end{array}$ & $\begin{array}{l}\text { of } \\
\text { Number } \\
\text { branch }\end{array}$ & $\begin{array}{l}\text { ofength } \\
\text { largest leaf }\end{array}$ & $\begin{array}{l}\text { of } \\
\text { largest leaf }\end{array}$ \\
\hline Stock with leaves & 43.83 & 15.46 & 2.82 & 7.47 & 3.78 \\
Stock without leaves & 39.78 & 11.32 & 2.48 & 6.57 & 3.40 \\
LSD at 5\% & 0.71 & 0.65 & 0.03 & 0.21 & 0.08 \\
LSD at 1\% & 0.99 & 0.90 & 0.04 & 0.29 & 0.12 \\
Level of significance & $* *$ & $* *$ & $* *$ & $* *$ & $* *$ \\
\hline
\end{tabular}

The highest number of leaves (15.62) and the maximum (2.82) number of branches produced in grafts obtained from rootstock with leaf might be due to adequate supply of photosynthates which accelerate the early bud break and maximum number of leaf emergence. . In an experiment with grafting of mango, Karim (2004) also observed the highest number of leaves (23.60) when grafting done retaining leaf on rootstock.

However, early establishment of graft union, vascular connection of scion and rootstock, mobilization of food reserves and increased photosynthesis helped to maintain higher growth rate of leaves so that the maximum length and breadth of the largest leaf were recorded from grafts retaining leaf on rootstock. Retention of leaves on rootstock facilitates carbohydrate production as a result proper supply of food is ensured that increased the cellular activities through rapid establishment of vascular connection between scion and rootstock. Aftab (2004) reported that scion should be defoliated 10 to 5 days before grafting operation and the rootstock should retain leaves below the graft union that gave higher stionic growth of mango. This result is also proved by Karim (2004), Khatun (2005), Biswas (2007), Debnath (2007).

\section{Conclusions}

The results on the different parameters of the study advocated that among four scion defoliation periods, scion defoliated 6 days before grafting showed the best results in all aspects. Again in case of retention of leaf on rootstock, rootstock with leaf gave the best results in comparison to the rootstock without leaf. Hence grafting may be practiced for large scale propagation of lime retaining leaves below grafting union as they perform photosynthesis and provide food and nutrient for growth and development of the grafts. Therefore it can be concluded for the highest growth of grafted lime plants cleft grafting could be done by using scions defoliated 6 days before grafting and retaining leaves with rootstock.

\section{Conflict of interest}

None to declare.

\section{References}

Aftab M, 2004. Effect of scion leaf defoliation and retention of rootstock leaf on the success and stionic growth in cleft grafting in mango cv. Amrapali, MS Thesis, Department of Horticulture, Bangladesh Agricultural University, Myrnensingh.

BBS (Bangladesh Bureau of Statistics), 2015. Year Book of Agricultural Statistics of Bangladesh, Planning Bangladesh Bureau of Statistics, Planning Division, Ministry of Planning, Government of the People's Republic of Bangladesh, Dhaka Banglades.

Biswas SR, 2007. Effect of scion maturity and stock leaf retention on the graft success and survivability of epicotyl grafting in Indian Olive, MS Thesis, Department of Horticulture, Bangladesh Agricultural University, Mymensingh.

Debanath S, 2007. Effect of scion maturity and stock leaf retention on the graft success and survivability of epicotyls grafting in two types of jackfruit, MS Thesis, Department of Horticulture, Bangladesh Agricultural University, Mymensingh. 
Dhakal BR and MN Honda, 1987. Effect of defoliation period and storage of scion shoots on success of veneer grafting in mango. Prog. Hort., 19: 167-170.

Ferguson U,1990. Citrus fruits processing. Horticultural Science, Florida.

Hartmann HT, DE Kester, FT Davies and RL Geneve, 1997. Plant Propagation Principles and Practices. Prentice Hall of India Private Ltd. New Delhi-110001.

Karim R, 2004. Effect of leaf and node retention in rootstock on epicotyle grafting in mango, MS Thesis, Department of Horticulture, Bangladesh Agricultural University, Mymensingh.

Khatun M, 2005. Effect of age of rootstock, leaf retention on rootstock on grafting success in two varities of indian olive, MS Thesis, Department of Horticulture, Bangladesh Agricultural University, Mymensingh.

Maiti SC P Biswas, 1980. Effect of scion variety type of scion shoot on success of epicotyle grafting of mango. Punjab Hort. J., 20:152-155.

Okwu DE, 2008. Citrus fruits: a rich source of phytochemicals and their roles in human health: a review. International Journal of Chemical Science, 6: 451-471.

Patil J D, DC Warke, VK Patil, and SN Gunjkar, 1981. Studies on wedge grafting in mango. Punjab Hort. J., 23: 29-33.

Patil RJ, 2009. Studies on isolation and characterization of bioactive compounds in lime [citrus aurantifolia (Christm) swingle], their antioxidant and anticancer properties, Ph.D Thesis, Department of Crop Physiology. College of Agriculture, Dharwad University of Agricultural Sciences Dharwad.

Reddy CV and KR Melanta, 1988. Effect of age of rootstock on the success of softwood in mango in containers and in situ. South Indian Hort., 36:143-145. 